\title{
Oat agriculture, cultivation and breeding targets: implications for human nutrition and health
}

\author{
Derek Stewart ${ }^{1,2 *}$ and Gordon McDougall ${ }^{1}$ \\ ${ }^{1}$ Environmental and Biochemical Sciences Group, The James Hutton Institute, Dundee DD2 5DA, Scotland, UK \\ ${ }^{2}$ BioForsk Nord-Holt, Postbox 2284, Trømso, Norway \\ (Submitted 7 October 2013 - Final revision received 1 July 2014 - Accepted 6 August 2014)
}

\begin{abstract}
Oats are undervalued in comparison with wheat, rice and barley, despite their unique composition that includes many of the nutrients required for health and a reduced risk of degenerative disease incidence. Furthermore, oats as whole grain and some of their associated products also contain $\beta$-glucan, a complex polysaccharide that has an approved health claim to reduce blood cholesterol levels and reduce the risk of CHD incidence if consumed at $\geq 3 \mathrm{~g} / \mathrm{d}$. At the agronomic level, oats exhibit optimal growth in regions of moderate temperature and long day length. In addition, they can tolerate wet weather and acidic soils more effectively than other cereals, such as wheat. Studies have shown that there is diversity in the content and composition of nutrients and health-beneficial components within the available wild and cultivated germplasm and that these are amenable to be enhanced by different agronomic practices as well as are susceptible to climatic variation. The advances in modern plant genetics, developed in sister cereals such as wheat, rice and barley, mean that oat development and exploitation should see an acceleration in the coming decade as they are adopted and applied. These advances include approaches such as genome sequencing, genotyping by sequencing and the allied next-level analytical approaches of RNA sequencing, transcriptome profiling and metabolomics. The collation and coordination of these approaches should lead to the generation of new, tailored oat varieties that are nutritionally enhanced and contain a greater proportion of health-beneficial components that can be translated through into a wide(r) range of consumer products with the ultimate hope of associated benefits to human health and nutrition.
\end{abstract}

Key words: Oats: Grains: Cereals: $\beta$-Glucan

In the preface to his seminal book on oats, Welch ${ }^{(1)}$ states that 'Oats have been likened to Cinderella, an attractive and productive servant, wholesome and dependable, almost thriving on neglect and disinterest, but overshadowed by more assertive if less attractive step-sisters. (O)ats remains a uniquely versatile crop and, like Cinderella, combines an air of robust romance with a powerful potential'. This truism will be expanded upon here and the case made for the future oats with respect to their place in agriculture and human nutrition as well as the consequences for oat breeding and the agrifood chain.

Oats (Avena sativa L.) have a long history of use as a nutritious foodstuff, with records suggesting that oats in a cultivated form have been in use since the Bronze Age ${ }^{(2)}$. They are a palatable and nutritious foodstuff, mainly supplying carbohydrate in the form of starch and with reasonably high lipid levels (Table 1). Furthermore, oats contain small quantities of several of the B vitamins, particularly thiamin, folic acid, biotin and pantothenic acid, and the protein contains a good balance of essential amino acids. Wholegrain products are significant contributors to our micronutrient intake, and oats are a good source of $\mathrm{Mn}, \mathrm{Mg}$, Se and Fe, as well as $\mathrm{Ca}, \mathrm{Zn}$ and $\mathrm{Cu}^{(1)}$. In addition, oats are by far the predominant source of the soluble fibre $\beta$-glucan relative to other grains. Indeed, $\beta$-glucan (oat and barley) is the basis of the Food and Drug Administration (USA) ${ }^{(3)}$ - and Joint Health Claims Initiative $(\mathrm{UK})^{(4)}$-approved health claims highlighting this component's (and therefore oats') ability to reduce blood cholesterol levels and the risk of CHD incidence (see Box 1, Stewart et al. ${ }^{(5)}$ in this Supplement). The underpinning basis and extent of the impact of $\beta$-glucan on CHD are dealt with by Thies et al. ${ }^{(6)}$ and the consequences of processing on oat nutritive and health-beneficial values by Decker et $a l .{ }^{(7)}$.

The fundamentals of oat biology with respect to grain biology and nutrient and health-beneficial component localisation are outwith the scope of this brief review of oat cultivation, agriculture and breeding, but are admirably covered by Miller \& Fulcher ${ }^{(8)}$. Briefly, oats can be divided into two classes hulled, comprising a groat enclosed in a hull, and naked, where the hull is lightly attached but lost during threshing with the latter (hull-free oats) deemed nutritionally superior to the former. The hull is largely composed of non-nutritive or

Abbreviations: DArT, diversity array technology; MW, molecular weight; N, fertiliser nitrogen. 
Table 1. Nutritional composition of oatmeal and wholemeal wheat flour ${ }^{\star} \dagger$

\begin{tabular}{|c|c|c|c|c|}
\hline Nutrients & Oatmeal $(100 \mathrm{~g})$ & Wholemeal wheat flour $(100 \mathrm{~g})$ & Oatmeal (40 g) & Wholemeal wheat flour $(40 \mathrm{~g})$ \\
\hline \multicolumn{5}{|l|}{ Energy } \\
\hline kcal & 401 & 310 & 160 & 124 \\
\hline $\mathrm{kJ}$ & 1678 & 1297 & 669 & 519 \\
\hline Protein $(\mathrm{g})$ & $12 \cdot 4$ & $12 \cdot 7$ & $5 \cdot 0$ & $5 \cdot 1$ \\
\hline Oil (g) & $8 \cdot 7$ & $2 \cdot 2$ & 3.5 & 0.9 \\
\hline Carbohydrate (g) & $72 \cdot 8$ & 63.9 & $29 \cdot 1$ & $25 \cdot 6$ \\
\hline Dietary fibre $(\mathrm{g})$ & $6 \cdot 8$ & $9 \cdot 0$ & $2 \cdot 7$ & 3.6 \\
\hline $\mathrm{K}(\mathrm{mg})$ & 370 & 340 & 148 & 136 \\
\hline $\mathrm{Ca}(\mathrm{mg})$ & 55 & 38 & 22 & 15 \\
\hline $\mathrm{Mg}(\mathrm{mg})$ & 110 & 120 & 44 & 48 \\
\hline$P(m g)$ & 380 & 320 & 152 & 128 \\
\hline $\mathrm{Fe}(\mathrm{mg})$ & $4 \cdot 1$ & 3.9 & 1.6 & 1.6 \\
\hline $\mathrm{Cu}(\mathrm{mg})$ & 0.23 & 0.45 & 0.09 & $0 \cdot 18$ \\
\hline $\mathrm{Zn}(\mathrm{mg})$ & $3 \cdot 3$ & $2 \cdot 9$ & $1 \cdot 3$ & $1 \cdot 2$ \\
\hline $\operatorname{Se}(\mu \mathrm{g}) \ddagger$ & 8.6 & 9.5 & 3.4 & $3 \cdot 8$ \\
\hline Vitamin E (mg) & $1 \cdot 7$ & 1.4 & 0.7 & $0 \cdot 6$ \\
\hline Thiamin (mg) & 0.50 & 0.47 & 0.20 & $0 \cdot 19$ \\
\hline Riboflavin (mg) & $0 \cdot 10$ & 0.09 & 0.04 & 0.036 \\
\hline Niacin $(\mathrm{mg})$ & 3.8 & $8 \cdot 2$ & 1.5 & 3.3 \\
\hline Vitamin $B_{6}(\mathrm{mg})$ & 0.12 & 0.50 & 0.05 & 0.2 \\
\hline Folic acid $(\mu \mathrm{g})$ & 60 & 57 & 24 & 23 \\
\hline
\end{tabular}

*Data taken from Welch ${ }^{(1)}$ and the US Department of Agriculture Nutrient Database ${ }^{(56)}$.

†The 100 and $40 \mathrm{~g}$ columns aid in interpretation with respect to labelling; normally $100 \mathrm{~g}$ is used as a standard amount against which nutritional content labelling is used and $40 \mathrm{~g}$ is a common suggested serving amount for oatmeal.

$\ddagger 14.0 \mu \mathrm{g} / 100 \mathrm{~g}$ - content is variable depending on soil and fertiliser regimen.

putatively anti-nutritive components such as hemicellulose, cellulose and lignin ${ }^{(9)}$, and the increased nutritive value of the naked oats is due to a proportional weight difference basis because of the absence of a hull.

\section{Cultivation and production}

Oat is a crop produced on a global scale, but not at the level exhibited by what can be considered as staple crops, such as maize, rice, wheat, barley and millet (Fig. 1). The latest complete set of figures from The Food and Agriculture Organization Corporate Statistical Database (faostat.fao.org) indicate that in 2012 the global oat production was 19.6 megatonnes $^{(10)}$. The US Department of Agriculture ${ }^{(11)}$ posted a preliminary figure of about 23.6 megatonnes for the 2013/2014 global oat production, a $10.6 \%$ increase over the 2012/2013 harvest. These production data indicate a significant reduction on the global total of 46.9 megatonnes in 1961 and are indicative of a progressive decrease in global production (Fig. 2). However, this trend is perhaps a composite of several factors: the lack of development of oats into multiple products (being addressed only now) combined with the dominance of wheat and barley. Furthermore, the greater approval of the aforementioned health claims ${ }^{(5)}$ has slowly worked its way down the production and product development chain and has seen a slow evolution of products developed that have seen an upswing in food-related utilisation. Indeed, Strychar ${ }^{(12)}$ has reported that feed (animal) use of oats had declined from 90 to $70 \%$ of global production with the commensurate upswing in food and industrial utilisation.

It is clear from the figures that there are favoured regions for growth for many crops, and oats are no exception. Oats tend to be grown in temperate regions (Fig. 3) with reasonably high rainfall levels and generally in areas that have moderate temperatures: mid to north Europe, the Russian Federation, the USA and Canada comprise the major production regions (Fig. 4 and Table 2 with references therein). Optimum growth conditions are conditions of moderate temperature and long day length. In general, they can tolerate wet weather and acidic soils more effectively than other cereals such as wheat. In addition, and again in comparison with other food cereals, they are relatively resistant to foliar diseases, while requiring comparatively fewer pesticide and fertiliser inputs ${ }^{(13)}$.

With respect to nutritive and health-beneficial values, there has been a significant level of study into the key factors that affect diversity and content. In essence, there are several drivers for this: cultivars (genetic diversity); soil; climate; agronomy. Changes in nutritive and health-beneficial values as a different cultivar (a cultivated variety of a plant that has been created or selected intentionally and maintained through cultivation) is assessed are well established. A study carried out by Doehlert et al. ${ }^{(14)}$ of twelve oat varieties showed that,

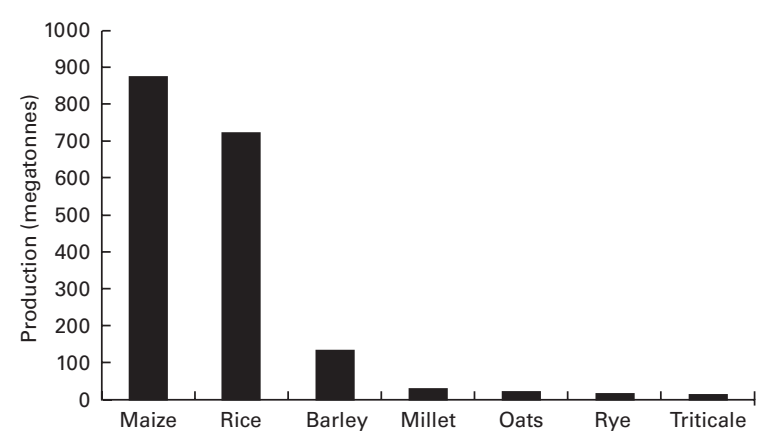

Fig. 1. Global production levels of the main cereal crops (values are for the 2010 production figures) $)^{(10)}$. 


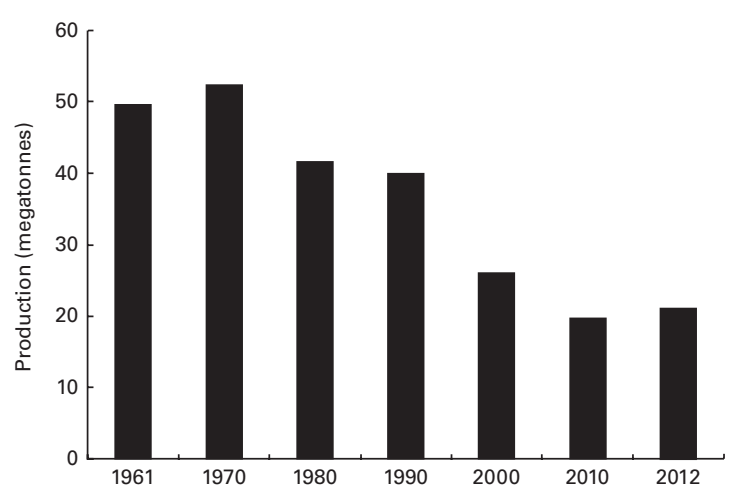

Fig. 2. Global production of oats from 1961 to $2010^{(10)}$.

even within this limited sample set of cultivated germplasm, the variation in grain yield and starch, oil, protein and $\beta$-glucan contents was significant at 31, 6, 34, 56 and 33\%, respectively. Other studies ${ }^{(15-27)}$ have focused more on specific components.

Leonova et $a l .{ }^{(15)}$ focused on oil content and diversity and reported that, although wild (uncultivated) oat species exhibited higher total oil (\% dry seed weight) and 18:1 fatty acid contents, the levels of the beneficial PUFA 18:2 (linoleic acid) and 18:3 (linolenic acid) were enhanced (as a \% of the total lipids) in cultivated oats. This corroborates the finding of other similar and limited studies ${ }^{(16,17)}$. More recently, a more extensive study ${ }^{(17)}$ using 917 oat accessions, mainly representing $A$. sativa but also including other Avena species (122 accessions) and cultivated oat replicated at different environments, has also confirmed the elevated levels of linoleic and $\alpha$-linolenic acids in the cultivated lines. Furthermore, this study found that environment significantly affected only total oil content and not the composition, which is in contrast to the findings of others ${ }^{(19-21)}$, who reported significant variation in composition. It is worth noting that in these latter studies the geographical variation was much broader than that utilised by Dhanda ${ }^{(18)}$.

The impact of oat genetic diversity is also evident for the health-beneficial component $\beta$-glucan, which is currently the main impetus behind much of the breeding effort in oats for human consumption. Several studies ${ }^{(22-26)}$ have been undertaken in this respect and have identified that the existing range of $\beta$-glucan content generally falls within $2.5-8.3 \%$ (dry grain). In addition to total $\beta$-glucan content, there is increasing interest in $\beta$-glucan polydispersity, essentially the relative distribution of polymer molar masses and degrees of polymerisation, with research pointing to biological efficacy and benefits deriving from the higher-molecular-weight components. In fact, molecular weight polydispersity is significant and has been reported to cover the range $65-3100 \mathrm{kDa}^{(27)}$.

The environment and agronomic systems can have significant effects on the nutritive and health-beneficial values of oats, and abiotic (non-biological) stress factors, such as temperature, drought/flooding and fertilisation, have been assessed for their impact (Table 2). In general, these stressors are combined under 'environment', despite fertilisation being an agronomic process, and the impact is assessed as such.
For example, Doehlert et al. ${ }^{(14)}$ reported that oat yield and starch content were strongly influenced by environment, whereas protein and $\beta$-glucan contents were equally susceptible to genetic and environmental influence. Interestingly, Andersson \& Börjesdotter ${ }^{(28)}$ reported a greater effect of environment on the molecular weight of $\beta$-glucan $(71 \%)$ than on its content ( $42 \%)$. It is worth stressing that these environmental effects do translate through to specific and quantifiable nutritional consequences. A study carried out by Dickin et $a l{ }^{(29)}$ on the impact of genotype, environment and agronomic management on $\beta$-glucan in naked barley grain (a sister species with appreciable $\beta$-glucan contents) highlighted that all these factors affected $\beta$-glucan content. Also, part of this study was a porridge intervention trial employing lines exhibiting variation in $\beta$-glucan content $(5 \cdot 8 v .4 .6 \mathrm{~g} / 100 \mathrm{~g}$ (dry material)) to highlight the impact of $\beta$-glucan content variation on human metabolism. In this trial, the higher$\beta$-glucan porridge was found to significantly reduce the total glucose released as well as blunt the peak glucose, a phenomenon associated with oxidative stress, inflammation responses and degenerative diseases such as endothelial dysfunction ${ }^{(30)}$.

A study carried out in Russia utilising a range of varieties from Germany, the USA, Russia, Canada, Sweden and other countries highlighted some broad environmental effects with oat yields being identified as susceptible to high temperature and drought ${ }^{(31)}$. Interestingly, Frey ${ }^{(32)}$ reported that the modern oat varieties were more tolerant to drought stress than older ones. Most studies on environmental effects on oats have targeted specific ( $\beta$-glucan, oil and protein) or gross (yield, lodging disease resistance) components. As has been mentioned above, $\beta$-glucan content and polydispersity have been shown to be environmentally influenced, and such studies have been extended to other beneficial components (Table 2). Unsurprisingly, protein content is responsive to fertiliser $\mathrm{N}$ addition, with total protein content being optimised by eliminating supraoptimal applied N. Interestingly, the nutritive value with respect to protein amino-acid content did differ between naked and husked oats in response to increasing $\mathrm{N}$ inputs ${ }^{(13)}$.

Oat, similar to any other crop, is a host for attack by plant pathogens, and this attack invariably reduces crop yield and affects composition and therefore the accessibility of highquality oat for human consumption. Of the viral pathogens,

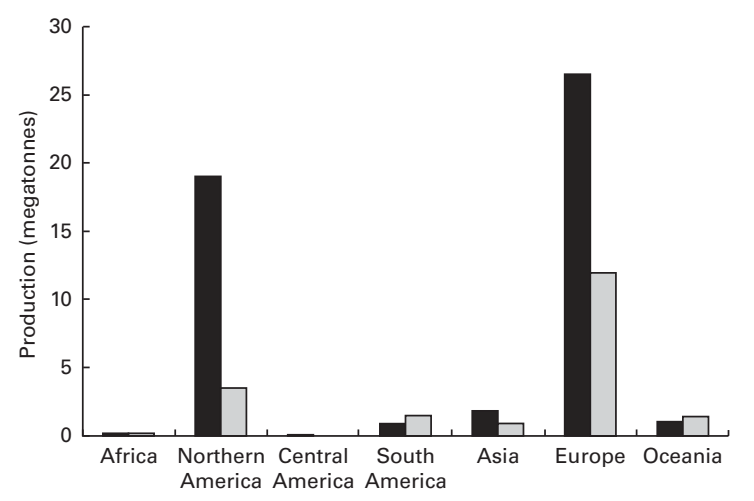

Fig. 3. Regionalised oat production for the years $1961(\square)$ and $2010(\square)^{(10)}$. 


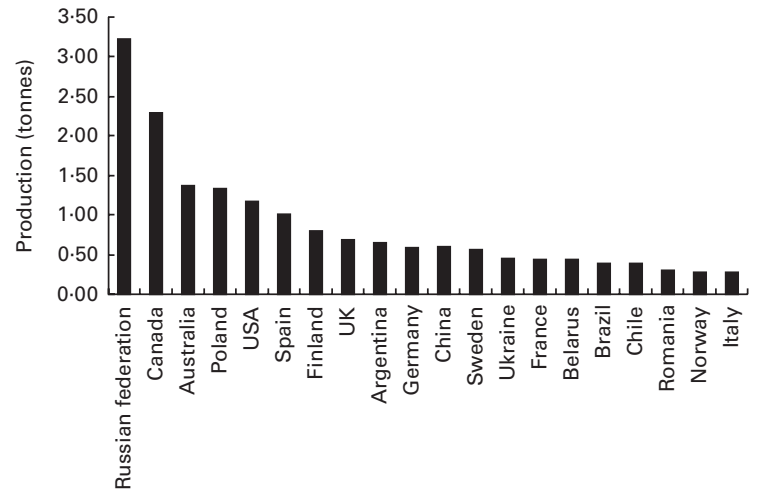

Fig. 4. Top twenty countries for oat production in $2010^{(10)}$.

barley yellow dwarf virus (also known as red leaf) can cause significant crop and yield losses ${ }^{(32)}$; crown rust ${ }^{(33)}$ (Puccinia coronata) and powdery mildew ${ }^{(34,35)}$ (Blumeria graminis) are the prevalent fungal diseases in North America and the cooler, humid regions of Europe, respectively.

However, it is the fungal infection of oats (and cereals) caused by species of the Fusarium genus that is of most concern to oat consumption and human health and wellbeing. These fungi are well reported to produce the mycotoxin trichothecenes, such as deoxynivalenol, nivalenol,
T-2 and HT-2, and some other toxins such as zearalenone and fumonisins $B_{1}$ and $B_{2}$, and the specific production of these toxins depends upon where the oat is grown and hence the localised fungal strain population ${ }^{(36,37)}$. The trichothecenes T-2 and HT-2 are the ones commonly reported in infected oats; the physiological consequences of consuming these either directly on the oat (products) or via animals fed with spoiled oat feed are acute, with chronic toxicity potentially leading to induced apoptosis in the immune system and fetal tissues ${ }^{(38)}$. A combined approach of targeting resistance in new varieties, particularly using modern genetic/genomic approaches, and adherence to good agricultural practices should see the current-day levels of these deleterious components dramatically reduced.

\section{Oat breeding: cultivars for climate adaptation and pathogen resistance}

The production and availability of oats are, as in all crops, affected by agricultural practices and climatic variation ${ }^{(39)}$, which in turn may affect plant diseases ${ }^{(40)}$. If agriculture is to provide sufficient food for a growing population, crops providing a significant complement of the human requirement for nutrition and energy, such as oats, must adapt to climate change ${ }^{(41)}$. These changes will include shifts to mid-latitudes

Table 2. Influence of environment factors on beneficial oat components

\begin{tabular}{|c|c|c|c|}
\hline Components & Environmental factor & Impact & Reference(s) \\
\hline \multirow[t]{3}{*}{$\beta$-Glucan - total } & Temperature & Generally higher levels in warm, dry climates & $\begin{array}{l}\text { Doehlert et al. }{ }^{(14)} \\
\text { Saasatamoinen } \\
\text { Anker-Nilssen et al. } \\
\text { Ans) }\end{array}$ \\
\hline & Precipitation & $\begin{array}{l}\text { Moderate rain increased total content. } \\
\text { Supraoptimal precipitation yields lower total contents }\end{array}$ & $\begin{array}{l}\text { Doehlert et al. } \\
\text { Brunner } \& \text { Freed }{ }^{(59)}, \text { Güler }^{(60)}\end{array}$ \\
\hline & Fertiliser & Total $\beta$-glucan is optimised by eliminating supraoptimal applied $N$ & $\begin{array}{l}\text { Achleitner et al. } \\
\quad \text { Weightman et al. }\end{array}$ \\
\hline \multirow[t]{3}{*}{$\begin{array}{l}\beta \text {-Glucan } \\
\text { polydispersity }\end{array}$} & Temperature & Elevated growing season temperature yields higher-MW $\beta$-glucan & $\begin{array}{l}\text { Anker-Nilssen et al. } \\
\quad \text { Ajithkumar et al. } \\
\text { (62) }\end{array}$ \\
\hline & Precipitation & Reduced the average MW & Andersson \& Börjesdotter ${ }^{(28)}$ \\
\hline & Fertiliser & $\begin{array}{l}\text { Optimising } N \text { increases total } \beta \text {-glucan content, } \\
\text { which is correlated with higher-MW } \beta \text {-glucan }\end{array}$ & Andersson \& Börjesdotter ${ }^{(28)}$ \\
\hline \multirow[t]{2}{*}{ Starch } & $\begin{array}{l}\text { Temperature } \\
\text { Precipitation }\end{array}$ & $\begin{array}{l}\text { Combined as environment - affects starch content, } \\
\text { Rapid Visco Analyser }{ }^{\mathrm{TM}} \text { pasting viscosities, } \\
\text { starch swelling volume and differential scanning } \\
\text { calorimetry thermal properties }\end{array}$ & Rhymer et al. ${ }^{(63)}$ \\
\hline & Fertiliser & $\begin{array}{l}\text { Cultivar-dependent response to } \mathrm{N} \text { levels: } \\
\text { optimising } \mathrm{N} \text { for yield can reduce starch content }\end{array}$ & Givens et al. ${ }^{(13)}$ \\
\hline \multirow[t]{2}{*}{ Protein } & Precipitation & $\begin{array}{l}\text { Increasing soil salinity reduced grain protein content. } \\
\text { General increase in dry conditions }\end{array}$ & Kumar et al. ${ }^{(64)}$, Peterson et al. ${ }^{(65)}$ \\
\hline & Fertiliser & $\begin{array}{l}\text { Total protein is optimised by eliminating supraoptimal applied } \\
\mathrm{N} \text {. Protein amino-acid compositional response observed between } \\
\text { naked and husked oats in response to increasing } \mathrm{N} \text { inputs }\end{array}$ & $\begin{array}{l}\text { Givens et al. }{ }^{(13)} \text {, } \\
\text { Weightman et al. } \\
\text { Welch \& Leggett }^{(66)} \text {, } \\
\text { Dimitrova-Doneva \& Petkova }\end{array}$ \\
\hline Oil & Fertiliser & $\begin{array}{l}\text { Generally a reduction in total oil content with increasing } \\
\text { added } N \text {. Conflicting reports on compositional changes: } \\
\text { small but significant increases in palmitic acid }(16: 0) \text { and } \\
\text { linoleic acid }(18: 2) \text { contents, but decreases in } \\
\text { oleic acid }(18: 1) \text { content with increasing } N \text { inputs }\end{array}$ & 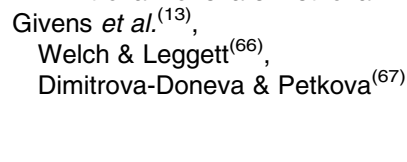 \\
\hline Phytochemicals & $\begin{array}{l}\text { Temperature } \\
\text { Precipitation }\end{array}$ & $\begin{array}{l}\text { Avenanthramides - Content is under environmental } \\
\text { influence but poorly defined }\end{array}$ & $\begin{array}{l}\text { Peterson et al. } \\
\text { Emmons }^{(65)} \text { Peterson } \\
(68)\end{array}$ \\
\hline & Fertiliser & $\begin{array}{l}\text { Addition of } P \text { sources can increase the levels of } \\
\text { the antinutrient phytic acid }\end{array}$ & Miller \& Fulcher ${ }^{(8)}$ \\
\hline
\end{tabular}

MW, molecular weight; $\mathrm{N}$, fertiliser nitrogen. 
and adaptations to broader temperature ranges, more frequent weather extremes, and longer growing seasons, a shift to sustainable agronomic practices using nutrient-use-efficient varieties (reduced synthetic fertiliser use), greater stress and drought resistance, and elevated dew points. Successful adaptations for oats will require extensive understanding of the molecular mechanisms and pathways involved in, and affected by, abiotic stress factors and sustainable agricultural practices ${ }^{(39-41)}$. An obvious approach to this understanding includes genetic modelling using tractable plant models such as Arabidopsis ${ }^{(42)}$ or, more sensibly, an appropriate sister cereal model, such as barley, which has recently had its genome sequenced $^{(43)}$. Furthermore, oat, as part of the cereal family, will benefit from the new initiatives such as Modelling European Agriculture with Climate Change for Food Security (http://www.macsur.eu/). This knowledge hub gathers the excellence of existing research in livestock, crop and trade science to describe how climate variability and change will affect regional farming systems and food production in Europe in the near and distant future and the associated risks and opportunities for European food security. Such synergistic programmes with modelling on a panEuropean scale will invariably benefit future crop-breeding initiatives and effort.

As has been highlighted earlier, powdery mildew, crown and stem rust, and infections caused by species of the Fusarium genus are the predominant diseases that affect oats and can reduce crop yield by as much as $50 \%$ among susceptible cultivars $^{(34-37)}$, with, for example, crown and stem rust contributing to significant global reduction in yield and seed quality $^{(32)}$. Barley yellow dwarf disease ${ }^{(33)}$, which has aphids as its primary vector, is considered the most important viral disease of oats, and currently none of the oat cultivars is highly resistant to barley yellow dwarf virus. However, this is a focus in the oat-breeding community, and the identification of cultivars exhibiting degrees of resistance (while maintaining/increasing grain yield) is providing a foundation for further genetic research ${ }^{(44,45)}$. Germplasm exchanges from specific oat cultivars since the late $1960 \mathrm{~s}$ indicate a steady improvement in barley yellow dwarf virus tolerance, and this breeding effort has - following multiple collaborative efforts between universities and agriculture centres involving multiple generations of oat genomic clones of global origin, selective crossbreeding and the application of newer genome-mining technologies such as diversity array technology ${ }^{(46,47)}$ (see below) - produced cultivars that are more resistant to barley yellow dwarf virus and exhibit increased yields.

\section{Oat breeding: state of the art and future plans}

Modern-day oat breeding has progressed significantly as a result of the paradigm shift that has occurred in plant biology with the combined advances in molecular biological research, omics technologies, genome sequencing and bioinformatics. Perhaps because oats have (unfairly) been perceived as a relatively unimportant crop, they have not benefited from the level of research that has been put into wheat, rice, barley and even sorghum - but progress has been made using the approaches mentioned above. Our understanding of oats per se and also our knowledge of the rate at which yield, disease resistance, and compositional content and diversity are being manipulated have increased significantly ${ }^{(44-47)}$. MacKey ${ }^{(48)}$, for example, highlighted that the yield potential of Swedish oat had remained virtually unchanged over the period from 1910 to 1960, whereupon it increased, with accompanying research effort yielding major increases in harvest index (the weight of a harvested product as a percentage of the total plant weight of a crop) and lodging resistance. This approach became the norm and, as the utility, nutritive value and health benefits (predominantly those attributable to $\beta$-glucan) became established, it became imperative that breeding needed to be able to manipulate, and ideally enhance, many of these traits simultaneously. Diverse germplasm has traditionally been used to modulate oat gross (e.g. yield) and specific ( $\beta$-glucan) parameters. However, modern genetic analytical approaches such as simple sequence repeats ${ }^{(49)}$, amplified fragment length polymorphisms ${ }^{(50)}$, restriction fragment length polymorphism ${ }^{(44)}$ and diversity array technology ${ }^{(46)}$ are being applied to oat per se either in isolation or in unison $^{(47)}$ to maximise the identification of genetic diversity.

Overall, these approaches identified that, due to the limited initial selection of landraces (essentially traditional localised varieties), diversity has become limited and that if there are to be significant increases in, for example, the levels of $\beta$-glucan and vitamins, reassessment and integration (introgression) of the wild material into breeding programmes are necessary. Such an approach is already being undertaken on a significant scale for sister grass species Lolium perenne (perennial ryegrass), with the introgression of the entire genome of Festuca pratensis (meadow fescue) into $L$. perenne in overlapping chromosomal segments with the aim of crop improvement by tapping the $F$. pratensis untapped reservoir of genetic variation for a wide range of agronomically important traits ${ }^{(51)}$. This approach, using a combination of modern genetic/genomic and high-throughput analytical approaches, makes this an achievable goal and one that can deliver on the development of oat for food uses as well as targeted utilisation in other sectors, such as cosmetics and food ingredients ${ }^{(52)}$

Modern commercial oat breeding is a complex and structured system that combines the selection and assessment of the breeding material and progeny, normally at a restricted acreage level, with the commercial trialling over broader and diverse environments (Fig. 5). As with other crops, this is a rolling-and-staggered approach to ensure the continuous production of better and distinct varieties that match the current and projected market requirements. It is clear that going forward there will be multiple targets for oat breeding to address ${ }^{(26,53)}$. From the aspect of new product development, these targets will undoubtedly include the following:

(1) Oat $\beta$-glucan - building on the approved health claim.

(2) Nutritional components - good source of protein and unsaturated fatty acids. 


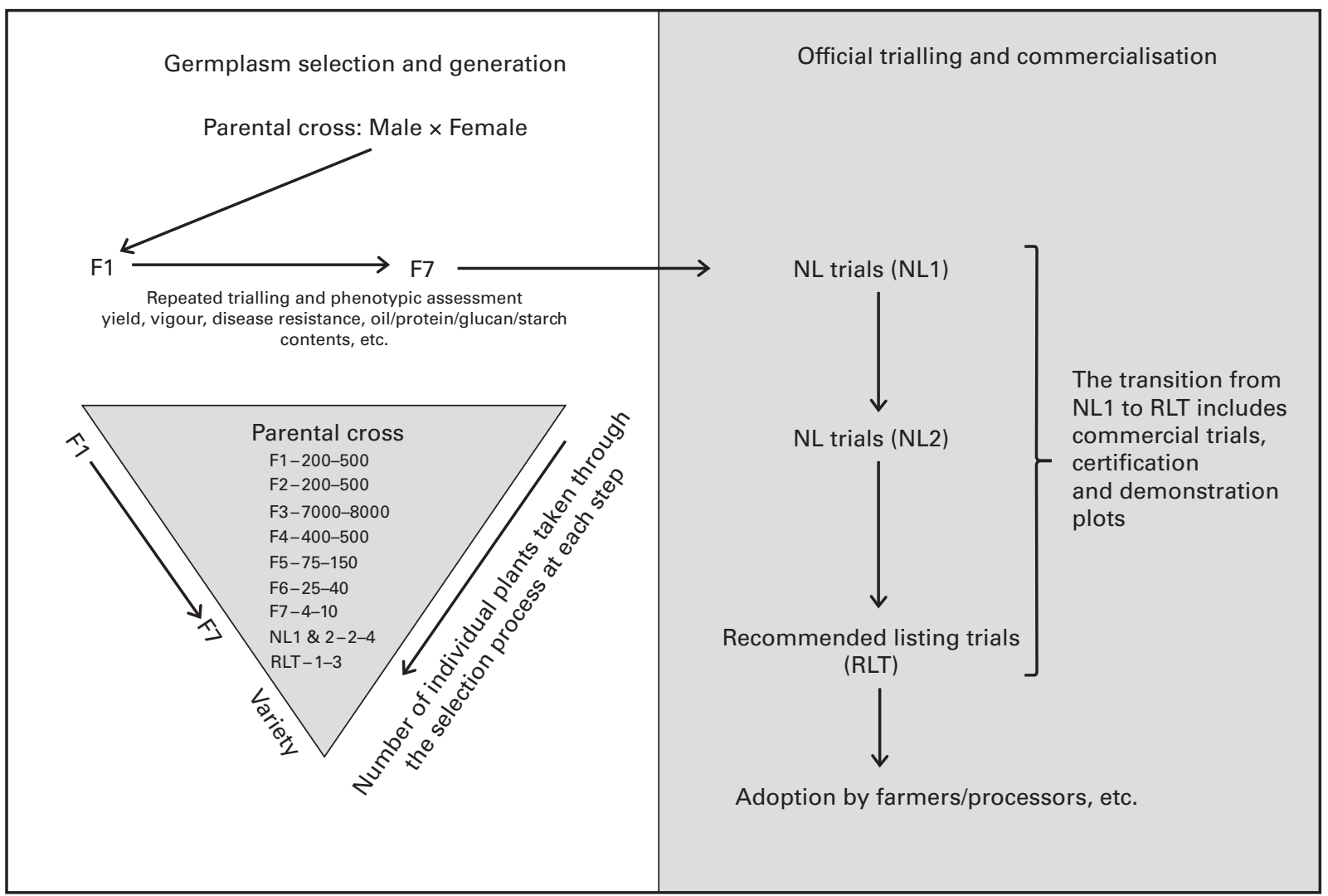

Fig. 5. A schematic description of the UK process of oat variety generation with approximations of the scale of effort involved. The parental cross schematic highlights the scale of plant lines needed to progress from the initial parental cross through generation to be multiplied up for assessment and ultimately for recommendation (RL) to farmers. NL (National Listing): this is a legal requirement for new varieties of the main agricultural and vegetable species that seeks to ensure that no new variety is marketed unless it is genuinely new and, for agricultural crops, an improvement in key characteristics on varieties already being sold. RL (Recommended Listing): this provides information on yield and quality performance, agronomic features and market options for recommended varieties to assist growers with variety selection. Varieties are generally trialled on an annual basis while they remain on the Recommended List. For oats in the UK, this is administered by the Home Grown Cereal Authority. RLT, Recommended Listing trials.

(3) Desirable organoleptic properties - these are predominantly derived from the action of processing/cooking on the oat lipid content and vary with process/cooking conditions and lipid composition.

\section{What does the future hold?}

The advances now being made in oat biology as a consequence of technological advancements in other cereals, such as rice, wheat and barley, are exponential. The adoption of genotype by sequencing ${ }^{(54)}$ holds major potential for identifying both the variation in and the genes underpinning the desirable nutritional and health-beneficial traits, meaning that these genome regions can then be used as molecular markers to accelerate trait enhancement in future germplasm. Furthermore, this approach can also be exploited along with transcriptome profiling that uses deep-sequencing technologies $^{(55)}$ to tease out the genetic drivers to the environmental response that we have already shown (Table 2) can impinge upon nutritional and health-beneficial contents. Alignment of this with high-throughput and detailed phenotyping systems, such as metabolomics, will ultimately lead to an accelerated development of new and tailored oat varieties.

The next step in the development of oats will be the elucidation of the genome sequence, and this is being actively pursued by a consortium of oat scientists across the world.

\section{Acknowledgements}

D. S. received an honorarium from Quaker Oats Company (a subsidiary of PepsiCo, Inc.) for attending a workshop in May 2012 to discuss the content of the supplement, and the James Hutton Institute received an unrestricted grant from the Quaker Oats Company. D. S. is part of the QUOATS Consortium (www.quoats.org), which is jointly sponsored by BBSRC, DEFRA, SG-RESAS, WAG, AHDB and industry partners. D. S. and G. M. acknowledge grant-in-aid and contract research funding from SG-RESAS for strategic research and MACSUR (www.macsur.eu) activities.

The authors' contributions are as follows: D. S. prepared the first draft of the paper; G. M. provided input to the introduction and content for the tables. Both authors reviewed and commented on the paper. 
This paper was published as part of a supplement to British Journal of Nutrition, publication of which was supported by an unrestricted educational grant from Quaker Oats Co. (a subsidiary of PepsiCo Inc.). The papers included in this supplement were invited by the Guest Editor and have undergone the standard journal formal review process. They may be cited.

The Guest Editor to this supplement is Roger Clemens. The Guest Editor declares no conflict of interest.

\section{References}

1. Welch RW (1995) Oats in human health and nutrition. In The Oat Crop: Production and Utilization. London: Chapman and Hall.

2. Baum BR (1977) Oats: Wild and Cultivated. A Monograph of the Genus Avena L. (Poaceae). Ottawa, ON: Agriculture Canada.

3. Food and Drug Administration (2008) \$101.81 Health Claims: Soluble Fiber from Certain Foods and Risk of Coronary Heart Disease (CHD): 21 CFR Ch. I (4-1-08 Edition). Washington, DC: US Access Board.

4. JHCI (Joint Health Claims Initiative) (2006) Generic claims oats and reduction of blood cholesterol. http://www.jhci.org. uk/approv/oats.htm (accessed December 2012).

5. Stewart D, Kennedy A \& Pavel A (2014) Beyond nutrition and agriculture policy: collaborating for a food policy. $\mathrm{BrJ}$ Nutr 112, S65-S74

6. Thies F, Masson LF, Boffetta P, et al. (2014) Oats and CVD risk markers: a systematic literature review. Br J Nutr 112, S19-S30.

7. Decker EA, Rose D \& Stewart D (2014) Processing of oats and the impact of processing operations on nutrition and health benefits. Br J Nutr 112, S58-S64.

8. Miller SS \& Fulcher RG (2011) Microstructure and chemistry of the oat kernel. In Oats: Chemistry and Technology, 2nd ed., pp. 77-94 [FH Webster and PJ Wood, editors]. Washington, DC: American Association of Cereal Chemists.

9. Thompson RK, Mustafa AF, McKinnon JJ, et al. (2000) Genotypic differences in chemical composition and ruminal degradability of oat hulls. Can J Anim Sci 80, 377-379.

10. Food and Agriculture Organization of the United Nations (2014) FAOSTAT. http://faostat.fao.org/ (accessed April 2014).

11. United States Department of Agriculture \& Foreign Agricultural Service (2014) Grain: world markets and trade http://apps.fas.usda.gov/psdonline/circulars/production.pdf (accessed 18 May 2014).

12. Strychar R (2011) World oat production, trade, and usage. In Oats: Chemistry and Technology, 2nd ed., pp. 77-94 [FH Webster and PJ Wood, editors]. Washington, DC: American Association of Cereal Chemists.

13. Givens I, Davies TW \& Laverick RM (2004) Effect of variety, nitrogen fertiliser and various agronomic factors on the nutritive value of husked and naked oats grain. Anim Feed Sci Technol 113, 169-181.

14. Doehlert DC, McMullen M \& Hammond JJ (2001) Genotypic and environmental effects on grain yield and quality of oat grown in North Dakota. Crop Sci 41, 1066-1072.

15. Leonova S, Shelenga T, Hamberg M, et al. (2008) Analysis of oil composition in cultivars and wild species of oat (Avena sp.). J Agric Food Chem 56, 7983-7991.

16. Frey KJ \& Hammond EG (1975) Genetics, characteristics, and utilization of oil in caryopses of oat species. $\mathrm{J} \mathrm{Am} \mathrm{Oil} \mathrm{Chem}$ Soc 975, 52358-53362.
17. Sahasrabudhe MR (1979) Lipid composition of oats (Avena sativa L.). J Am Oil Chem Soc 56, 80-84.

18. Dhanda RK (2011) Fatty acid composition in diverse oat germplasm. MSc Thesis, University of Saskatchewan. http:// ecommons.usask.ca/handle/10388/etd-03202011-224522 (accessed June 2013).

19. Welch RW (1975) Fatty acid composition of grain from winter and spring sown oats, barley and wheat. J Sci Food Agric 26, 429-435.

20. Rezai A \& Frey KJ (1988) Variation in relation to geographical distribution of wild oats - seed traits. Euphytica 39, 113-118.

21. Saastamoinen M, Kumpulainen J \& Nummela S (1989) Genetic and environmental variation in oil content and fatty acid composition of oats. Cereal Chem 66, 296-300.

22. Lee CJ, Horsley RD, Manthey FA, et al. (1997) Comparisons of $\beta$-glucan content of barley and oat. Cereal Chem $\mathbf{7 4}$, $571-575$.

23. Åman P \& Graham H (1987) Analysis of total and insoluble mixed linked $(1 \rightarrow 3)$, $(1 \rightarrow 4)-\beta$-D-glucans in barley and oats. J Agric Food Chem 35, 704-709.

24. Åman P, Graham H \& Tilley A (1989) Content and solubility of mixed-linked $(1 \rightarrow 3)$, $(1 \rightarrow 4)-\beta$-D-glucan in barley and oats during kernel development and storage. J Cereal Sci 10, $45-50$.

25. Cervantes-Martinez CT, Frey KJ \& White PJ (2001) Selection for greater $\beta$-glucan content in oat grain. Crop Sci $\mathbf{4 1}$, 1085-1091.

26. Newell MA, Asoro FG, Scott MP, et al. (2012) Genome-wide association study for oat (Avena sativa L.) $\beta$-glucan concentration using germplasm of worldwide origin. Theor Appl Genet 125, 1687-1696.

27. Lazaridou A \& Biliaderis CG (2007) Molecular aspects of cereal $\beta$-glucan functionality: physical properties, technological applications and physiological effects. J Cereal Sci 46, 101-118.

28. Andersson AAM \& Börjesdotter D (2011) Effects of environment and variety on content and molecular weight of $\beta$-glucan in oats. J Cereal Sci 54, 122-128.

29. Dickin E, Steele K, Frost G, et al. (2011) Effect of genotype, environment and agronomic management on $\beta$-glucan concentration of naked barley grain intended for health food use. J Cereal Sci 54, 44-52.

30. Ceriello A, Esposito K, Piconi L, et al. (2008) Glucose 'peak' and glucose 'spike': impact on endothelial function and oxidative stress. Diabetes Res Clin Pract 82, 262-267.

31. Tamm I (2003) Genetic and environmental variation of grain yield of oat varieties. Agron Res 1, 93-97.

32. Frey K (1998) Genetic responses of oat genotypes to environmental factors. Field Crops Res 56, 183-185.

33. Jin H, Domier LL, Kolb FL, et al. (1998) Identification of quantitative loci for tolerance to barley yellow dwarf virus in oat. Phytopathology 88, 410-415.

34. Jackson EW, Obert DE, Avant JB, et al. (2010) Quantitative trait loci in the Ogle/TAM O-301 oat mapping population controlling resistance to Puccinia coronata in the field. Phytopathology 100, 484-492.

35. Roderick HW, Jones ERL \& Sebesta J (2000) Resistance to oat powdery mildew in Britain and Europe: a review. Ann Appl Biol 136, 85-91.

36. European Commission (2006) Commission recommendation on the prevention and reduction of Fusarium toxins in cereals and cereal products: principles for the prevention and reduction of Fusarium toxin contamination in cereals. Official J Eur Union 583, 234-237. 
37. Edwards SG, Imathiu SM, Ray RV, et al. (2012) Molecular studies to identify the Fusarium species responsible for HT-2 and T-2 mycotoxins in UK oats. Int J Food Microbiol 156, $168-175$.

38. Li Y, Wang Z \& Beier RC (2011) T-2 toxin, a trichothecene mycotoxin: review of toxicity, metabolism, and analytical methods. J Agric Food Chem 59, 3441-3453.

39. Ziska LH, Bunce JA, Shimono H, et al. (2012) Food security and climate change: on the potential to adapt global crop production by active selection to rising atmospheric carbon dioxide. Proc Biol Sci 279, 4097-4105.

40. Chakraborty S, Tiedemann AV \& Teng PS (2000) Climate change: potential impact on plant diseases. Environ Pollut 108, $317-326$.

41. Food and Agriculture Organization of the United Nations (2013) Climate-smart agriculture sourcebook. http://www. fao.org/docrep/018/i3325e/i3325e.pdf (accessed June 2013).

42. Chawade A, Bräutigam M, Lindlöf A, et al. (2007) Putative cold acclimation pathways in Arabidopsis thaliana identified by a combined analysis of mRNA co-expression patterns, promoter motifs and transcription factors. BMC Genomics $\mathbf{8}$, 304-318.

43. The International Barley Genome Sequencing Consortium (2012) A physical, genetic and functional sequence assembly of the barley genome. Nature 491, 711-716.

44. Sanz MJ, Loarce Y, Fominaya A, et al. (2013) Identification of RFLP and NBS/PK profiling markers for disease resistance loci in genetic maps of oats. Theor Appl Genet 126, 203-218.

45. McCartney CA, Stonehouse RG, Rossnagel BG, et al. (2011) Mapping of the oat crown rust resistance gene Pc91. Theor Appl Genet 122, 317-325.

46. Tinker NA, Kilian A, Wight CP, et al. (2009) New DArT markers for oat provide enhanced map coverage and global germplasm characterization. BMC Genomics 10, 38-61.

47. He X \& Bjørnstad A (2012) Diversity of North European oat analyzed by SSR, AFLP and DArT markers. Theor Appl Genet 125, 57-70.

48. MacKey J (1994) The history of cereal yield increase. Melhoramento 33, 37-53.

49. Fu YB, Chong J, Fetch T, et al. (2007) Microsatellite variation in Avena sterilis oat germplasm. Theor Appl Genet 114, 1029-1038.

50. Achleitner A, Tinker NA, Zechner E, et al. (2008) Genetic diversity among oat varieties of worldwide origin and associations of AFLP markers with quantitative traits. Theor Appl Genet 117, 1041-1053.

51. King J, Armstead I, Harper J, et al. (2013) Exploitation of interspecific diversity for monocot crop improvement. Heredity 110, 475-483.

52. Weightman R, Laverick R \& Maunsell C (2002) Oatec: New Technology for New Markets. Cambridge: Cambridge Marketing.
53. Tanhuanpää $\mathrm{P}$, Manninen $\mathrm{O}$, Beattie A, et al. (2012) An updated doubled haploid oat linkage map and QTL mapping of agronomic and grain quality traits from Canadian field trials. Genome 55, 289-301.

54. Luo X, Wight CP, Zhou Y, et al. (2012) Characterization of chromosome-specific genomic DNA from hexaploid oat. Genome 55, 265-268.

55. Wang Z, Gerstein M \& Snyder M (2009) RNA-Seq: a revolutionary tool for transcriptomics. Nat Rev Genet 10, 57-63.

56. USDA (2013) USDA Nutrient Database - Release 25. http:// ndb.nal.usda.gov/ (accessed April 2013).

57. Saasatamoinen M (1995) Effects of environmental factors on the $\beta$-glucan content of two oat varieties. Acta Agric Scand Sect B Soil Plant Sci 45, 181-187.

58. Anker-Nilssen K, Sahlstrøm S, Knutse SH, et al. (2008) Influence of growth temperature on content, viscosity and relative molecular weight of water-soluble $\beta$-glucans in barley (Hordeum vulgare L.). J Cereal Sci 48, 670-677.

59. Brunner BR \& Freed RD (1994) Oat grain $\beta$-glucan content as affected by nitrogen level, location and year. Crop Sci 34, 473-476.

60. Güler M (2011) Nitrogen and irrigation effects on grain $\beta$-glucan content of oats (Avena sativa L.). Aus J Crop Sci 5, 242-247.

61. Weightman RM, Heywood C, Wade A, et al. (2004) Relationship between grain $(1 \rightarrow 3,1 \rightarrow 4)$ - $\beta$-D-glucan concentration and the response of winter-sown oats to contrasting forms of applied nitrogen. J Cereal Sci 40, 81-86.

62. Ajithkumar A, Andersson R \& Aman P (2005) Content and molecular weight of extractable $\beta$-glucan in American and Swedish oat samples. J Agric Food Chem 53, 1205-1209.

63. Rhymer C, Ames N, Malcolmson L, et al. (2005) Effects of genotype and environment on the starch properties and end-product quality of oats. Cereal Chem 82, 197-203.

64. Kumar A, Agarwal S, Kumar P, et al. (2010) Effects of salinity on leaf and grain protein in some genotypes of oat (Avena sativa L.). Recent Res Sci Technol 2, 85-87.

65. Peterson DM, Wesenberg DM, Burrup DE, et al. (2005) Relationship among agronomic traits and grain composition in oat genotypes grown in different environments. Crop Sci 45, 1249-1255.

66. Welch RW \& Leggett JM (1997) Nitrogen content, oil content and oil composition of oat cultivars (A. sativa) and wild Avena species in relation to nitrogen fertility, yield and partitioning of assimilates. J Cereal Sci 26, 105-120.

67. Dimitrova-Doneva M \& Petkova R (2010) Effect of fertilization and predecessor on chemical composition and energy value of wintering oats grain. Agric Sci Technol 2, 139-142.

68. Emmons CL \& Peterson DM (2001) Antioxidant activity and phenolic content of oats as affected by cultivar and location. Crop Sci 41, 1676-1681. 